AperTO - Archivio Istituzionale Open Access dell'Università di Torino

\title{
Antifungal Susceptibility of Canine and Feline Malassezia spp. Isolates to Lactoferricin: Preliminary In-Vitro Study
}

\section{This is the author's manuscript}

Original Citation:

Availability:

This version is available http://hdl.handle.net/2318/1633694

since 2017-05-14T14:26:55Z

Published version:

DOI:10.1016/j.jcpa.2016.11.136

Terms of use:

Open Access

Anyone can freely access the full text of works made available as "Open Access". Works made available under a Creative Commons license can be used according to the terms and conditions of said license. Use of all other works requires consent of the right holder (author or publisher) if not exempted from copyright protection by the applicable law. 


\section{ANTIFUNGAL SUSGEPTIBILITY OF GANINE AND FELINE MALASSEZIA SPP. ISOLATES TO LACTOFERRIGIN: PRELIMINARY IN-VITRO STUDY

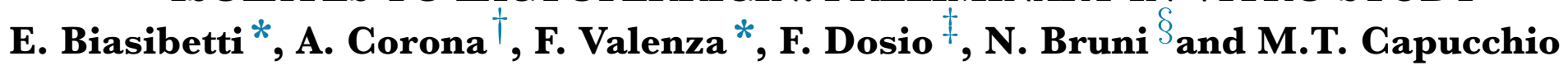 * Department of Veterinary Sciences, University of Torino, Torino, $\dagger$ Ambulatorio Veterinario Associato, Torino, ${ }_{5}$ Department of Drug Science and Technology, University of Torino, Torino and $\S$ Istituto Farmaceutico Candioli, Beinasco, Torino, Italy}

Introduction: Malassezia spp. is a fungus isolated from the skin and mucosae of dogs and cats, which may cause dermatitis and otitis. Therapies include the use of antibiotics, antifungals and glucocorti-coids. Because of the antibiotic-resistance phenomenon, new alterna-tive therapies are necessary. Bovine lactoferricin (Lfc) is a peptide derived from proteolytic cleavage of lactoferrin with proven antibac-terial, antifungal and immunostimulatory activity. The aim of this study was to evaluate the antifungal susceptibility of Malassezia spp. to Lfc-Candioli Pharma (water solution 20\%) using a microdilution method.

Materials and Methods: Fifty strains of Malassezia spp. collected from 50 animals (five cats, 45 dogs) affected by dermatitis and/or otitis externa and classified based on clinical signs and/or skin biopsies were cultured on Sabouraud's dextrose broth. Minimal inhibitory concentrations of Lfc were measured using the following concentra-tions: $13.3 \%, 10 \%, 6.7 \%, 3.3 \%$ and $1.8 \%$. Plates were incubated at $35^{\circ} \mathrm{C}$ and read 4 days after inoculation. To check the reproducibility of the procedure, all of the isolates were double tested and qual-ity controls were performed.

Results: All isolates were inhibited by Lfc with different minimum inhibitory concentration value. The product showed antifungal effi-cacy of $100 \%$ up to a dilution corresponding to $10 \%$ of Lfc. The first resistance was observed from $6.7 \%$ to the total resistance of $1.8 \%$.

Conclusions: These results suggest a potential antifungal efficacy of Lfc in vivo, even if in-vitro data should be considered with caution un-til standardized methods and correlation with clinical outcomes has been evaluated. 